\title{
An integrated approach to the study of catastrophic debris-flows: geological hazard and human influence
}

\author{
C. Del Ventisette, F. Garfagnoli, A. Ciampalini, A. Battistini, G. Gigli, S. Moretti, and N. Casagli \\ Department of Earth Sciences, University of Firenze, Via La Pira 4, 50121, Firenze, Italy
}

Correspondence to: C. Del Ventisette (chiara.delventisette@unifi.it)

Received: 29 November 2011 - Revised: 16 August 2012 - Accepted: 19 August 2012 - Published: 14 September 2012

\begin{abstract}
On 1 October 2009, a prolonged and intense rainstorm triggered hundreds of landslides (predominantly debris flows) in an area of about $50 \mathrm{~km}^{2}$ in the north-eastern sector of Sicily (Italy). Debris flows swept the highest parts of many villages and passed over the SS114 state highway and the Messina-Catania railway, causing more than 30 fatalities.

This region has a high relief, due to recent uplift. The peculiar geological and geomorphological framework represents one of the most common predisposing causes of rainstormtriggered debris flows. This paper deals with the geological and hydro-geomorphological studies performed as a part of the post-disaster activities operated in collaboration with Civil Protection Authority, with the aim at examining landslides effects and mechanisms. The data were elaborated into a GIS platform, to evaluate the influence of urbanisation on the drainage pattern, and were correlated with the lithological and structural framework of the area.

Our study points at the evaluation of the volume involved, the detection of triggering mechanisms and the precise reconstruction of the influence of urbanisation as fundamental tools for understanding the dynamics of catastrophic landslides. This kind of analysis, including all the desirable approaches for the correct management of debris flow should be the starting point for robust urban planning.
\end{abstract}

\section{Introduction}

Globally, landslides are one of the most important geological hazards and are responsible for substantial human and economic losses. Italy represents an especially high hazard area because of its geological and morphological characteristics ( $75 \%$ of the national territory is mountainous-hilly). In general, areas with steep slope gradients and availability of loose debris, dissected into small subcatchments with accelerated runoff and short response times, are preconditioned to destructive debris flows, generally triggered by heavy rainfall events. Debris flows are defined as very rapid to extremely rapid flows (velocity $>3 \mathrm{~m} \mathrm{~min}^{-1}=5 \times 10^{-2} \mathrm{~m} \mathrm{~s}^{-1}$; Cruden and Varnes, 1996) of saturated non-plastic debris in a steep channel. Following Hungr et al. (2001), the key characteristics of debris flows are: (1) presence of an established channel or a regular confined path; (2) a certain degree of rough sorting of the involved material, which tends to move the largest boulders towards the flow surface. This process produces a longitudinal sorting and the gathering of boulders near the front, thus, increasing the destructive potential of the slide (Pierson, 1986); (3) complete saturation: the water content can be highly variable depending on the heterogeneity of debris flow surges and varies temporally, as a result of the gradual dilution of the mass as it progresses downstream (Iverson, 1997).

Debris-flow behaviour is mostly controlled directly by variations in bulk-sediment concentration and by its influence on flow rheology, resulting in an increase of destructive power with density ("runoff-generated debris flows": Hungr et al., 2008). A hydrometeorological event which is intense enough to saturate the soil and to induce sufficient pore-water pressure, occurring in an area characterised by loose materials on steep slopes, can trigger debris flows (Zimmermann and Haeberli, 1992; Pierson et al., 1990; O'Connor et al., 1997; Johnson, 1984; Iverson, 1997). When poorly channelled, debris flows become debris avalanches (very rapid to extremely rapid shallow flows of partially or fully saturated debris on a steep slope, without confinement in an established channel: Hungr et al., 2001). Debris avalanches may, in turn, enter steep drainage channels or gullies and become debris flows. Debris flows can originate by various 
means (e.g., Pierson et al., 1990; Johnson, 1984; Iverson, 1997). According to Zimmermann and Haeberli (1992), the triggering factors of a debris flow are both direct and indirect. A hydrometeorological event is a direct cause, whereas the geotechnical properties of loose materials and their potential instability on a steep slope are indirect causes. The shallow groundwater flow, in response to rainfall surface runoff, triggers most subaerial debris flows. The key hydrologic requisites for debris-flow mobilisation are sufficient water to saturate the soil (direct cause) and sufficient porewater pressure and/or weight to initiate slope failure (Iverson, 1997). A violent storm, started during the afternoon of 30 September 2009 and struck Sicily, particularly affecting the province of Messina. For 1 October 2009, the pluviometric data point to a cumulative precipitation of more than $220 \mathrm{~mm}$ in a time span of $7 \mathrm{~h}$, characterised by several highintensity rainfall peaks. This particular rainfall event was preceded by at least two other intense rainstorm episodes, on 16 and 23-24 September. As a consequence, more than 600 debris flows (Ardizzone et al., 2012) occurred in the Messina province on 1 October. The same region had already been subjected to a similar event, although without loss of human life, after an intense rainstorm on 25 October 2007. The landslides blocked many stretches of the road system including main highways (the A/18 Messina-Catania highway and the State highway 114), the Giampilieri-Scaletta Zanclea railway and flooded ground floors and basements of buildings, underpasses and tunnels. The worst damage occurred in the village of Giampilieri, where many buildings collapsed. The total number of victims caused by the disaster reaches 31 , along with 122 injured people and 2019 evacuated people. Flowtype landslides represent one of the most dangerous landslide type. Over the years, many classifications have been proposed; in this paper the classification proposed by Hungr et al. (2001) is adopted, according to which the landslides triggered by the October 2009 intense rainfall can be prevalently classified as debris flows, locally evolved in debris floods, and debris avalanches. Immediately after the catastrophic episode, the Civil Protection Authorities organised emergency search and rescue services, evacuation of the population, digging for restoration of road practicability; contemporaneously, the research groups of the National Department of Civil Protection (including the University of Florence) were alerted; on-site surveys and studies aimed at restoring the course of daily activities in the villages were quickly planned and carried out. An examination of the evacuated areas and buildings was performed in order to distinguish according to damage evaluation, actual extension of the debris flows. Moreover, to gain a better understanding of the factors contributing to the initiation, magnitude and effects of the landslides, field-based geological and geomorphological studies as well as a digital elevation model (DEM) analysis were performed.

Among the villages involved in the landslides, the case study of Giampilieri was chosen. In this village seven catas- trophic flow-type landslides with different characteristics developed in a small area. The landslides caused fatalities and injuries, breaches to the road and rail networks, loss of power and telecommunications and serious damage to other infrastructures and to public and private buildings. In this paper, we present the results obtained by different methodologies (i.e., geological and geomorphological mapping, DEM analysis, debris flow intensity index (DSI)) that could be a useful tool to develop a proper urban planning in areas subjected to debris flows hazard.

\section{Geological and geomorphological background}

The study area is located in the province of Messina, on the slopes of the Peloritani Mountain Belt, to the north-east of the Etna volcano and represents a segment of the ApennineMaghrebide Orogen (Ogniben, 1960), a pre-Burdigalian collisional building (Lentini et al., 1995; Bonardi et al., 2003), developed on the African continental margin, after the subduction of the Ionian oceanic crust (Lentini et al., 1987). An allochtonous structural pile, formed by the Kabilo-Calabride Units and by the Apenninic-Maghrebid Units, is overthrust to the south onto the Iblean foreland. The Kabilo-Calabride Units, outcropping in the Messina area (Fig. 1), are made of continental crust fragments derived from the European margin and in particular by Hercinian crystalline rocks, with their Mesozoic-Tertiary covers (Ben Avraham et al., 1990; Lentini et al., 1994).

The Peloritani Mountain Belt was formed by the superimposition, through S-SW verging Aquitanian thrusts, of the following tectono-stratigraphic units (from bottom to top): Longi-Taormina, Fondachelli, Alì, Mandanici, Piraino, Mela and Aspromonte units (Messina et al., 2004).

Both the orogenic and foreland structures are cut and lowered towards the Ionian Basin by regional scale NNE-SSW normal fault systems (Messina-Etna System), characterised by remarkable displacements during the Holocene (Antonioli et al., 2006) and responsible for intense seismic activity, uplift and sea-level change in northeast Sicily (Lentini et al., 2000 and references therein; Antonioli et al., 2006).

The study area (Fig. 1) stretches astride the main backbone of the Peloritani Mountains, separating the Tyrrhenian side from the Ionian side. The geomorphological features of all the Peloritani Mountain Belt are those typical of recently uplifted areas, developed on a crystalline basement: a rugged and uneven landscape, with steep slopes eroded by torrent-like straight watercourses, narrow and deeply embanked into high rock walls in the mountain sectors, becoming wide and over-flooded in the terminal parts. The intermediate areas are often characterised by coalescent and extensive alluvial conoids or dejection cones. The river-beds lack downflows for most of the year, but they become substantial and very rich in solid material during the rainy season (autumn and winter), characterised by intense and 


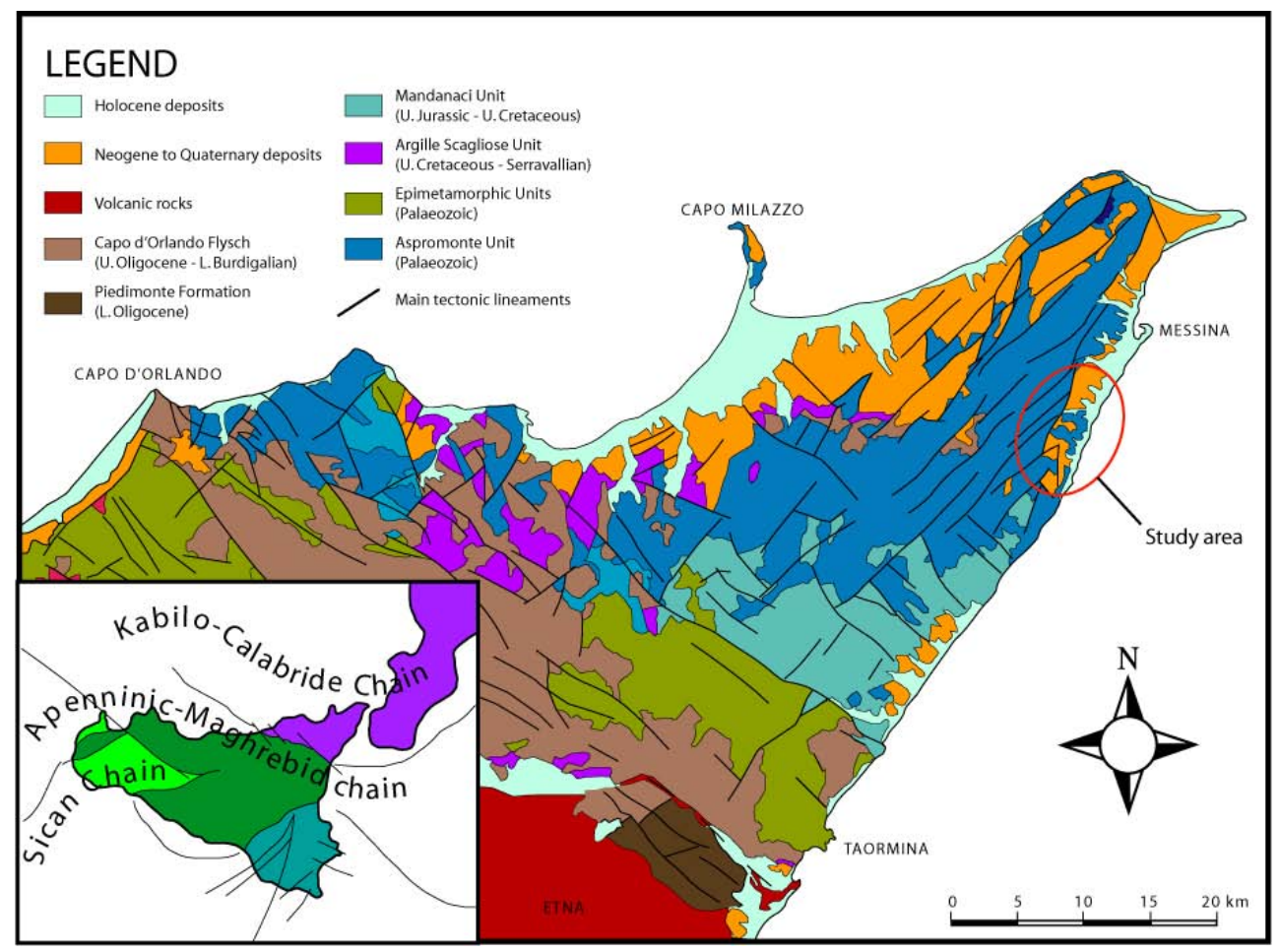

Fig. 1. Regional tectonic setting of the study area (redrawn from Lentini et al., 2000) with location of study area.

concentrated meteorological events. The hydrographic network is defined by many short incisions generally perpendicular (NW-SE) with respect to the Peloritani ridge. The study area is completely comprised in the Giampilieri torrent catchment, flowing into the Ionian sea, reaching a maximum height of $1040 \mathrm{~m}$ a.s.l., while the maximum elevation of the main fluvial channel is $924 \mathrm{~m}$ a.s.l.

Most of the steep slopes surrounding the village were historically devoted to agricultural practices, as testified by the frequent occurrence of dry stone walls.

\section{October 2009 event}

The geological and geomorphological features of the area, as well as the geotechnical properties of the terrains and the considerable steepness of the slopes, represent typical predisposing factors to landslide occurrence.

Long-term precipitations average for this area were calculated on a historical $77 \mathrm{yr}$ record of pluviometric data from the Santo Stefano di Briga weather station, available on the Sicily Region website (http://www.osservatorioacque. $\mathrm{it} /$ ?cmd=page $\backslash \& \mathrm{id}=$ dati_annali_int_pmensili); these showed that the October 1st 2009 event was exceptional. The average annual precipitation was $950 \mathrm{~mm} \mathrm{y}^{-1}$, while the seasonal averages were $360 \mathrm{~mm}$ in the period January-March, $110 \mathrm{~mm}$ in the period April-June, $95 \mathrm{~mm}$ in the period JulySeptember and $395 \mathrm{~mm}$ in the period October-December.
The assessment of the hydrometereological events was possible thanks to the analysis of daily precipitation data provided by the Italian Civil Protection (Fig. 2), covering the period between January 2007 and December 2009. Both the considered weather stations (Santo Stefano di Briga and Fiumedinisi, located about $3.5 \mathrm{~km}$ north and $9 \mathrm{~km}$ south of Giampilieri, respectively), recorded an increase of the total precipitation in the examined period with peaks in October 2007 and September 2009 (Fig. 2), which are corresponding with the catastrophic effects observed on the ground. The total rainfall from 15 September to 1 October, amounted to approximately $500 \mathrm{~mm}$ in the most affected area. On 1 October an average intensity of $31.8 \mathrm{~mm} \mathrm{~h}^{-1}$ was registered; considerably intense showers occurred, with a maximum intensity of $2 \mathrm{~mm} \mathrm{~min}^{-1}$ (report on meteorological events, 1 October 2009, region of Sicily - Civil Protection Agency, 2009). These values exceed the intensity thresholds established worldwide (Govi and Sorzana, 1980; Moser and Hohensinn, 1983; Wieczorek, 1987; Carson, 1988) and locally (Guzzetti et al., 2007; Brunetti et al., 2010) for the initiation of debris flows.

Almost all the landslides in Giampilieri started from sites characterised by a high flow concentration, linked to the geological-geomorphological setting or to anthropogenic causes (roads with inadequate drainage system and agricultural terraces). The superficial colluvial and alluvial terrains were involved to a variable extent (up to a maximum thickness of $1.5-2 \mathrm{~m}$ ) and locally completely removed. 

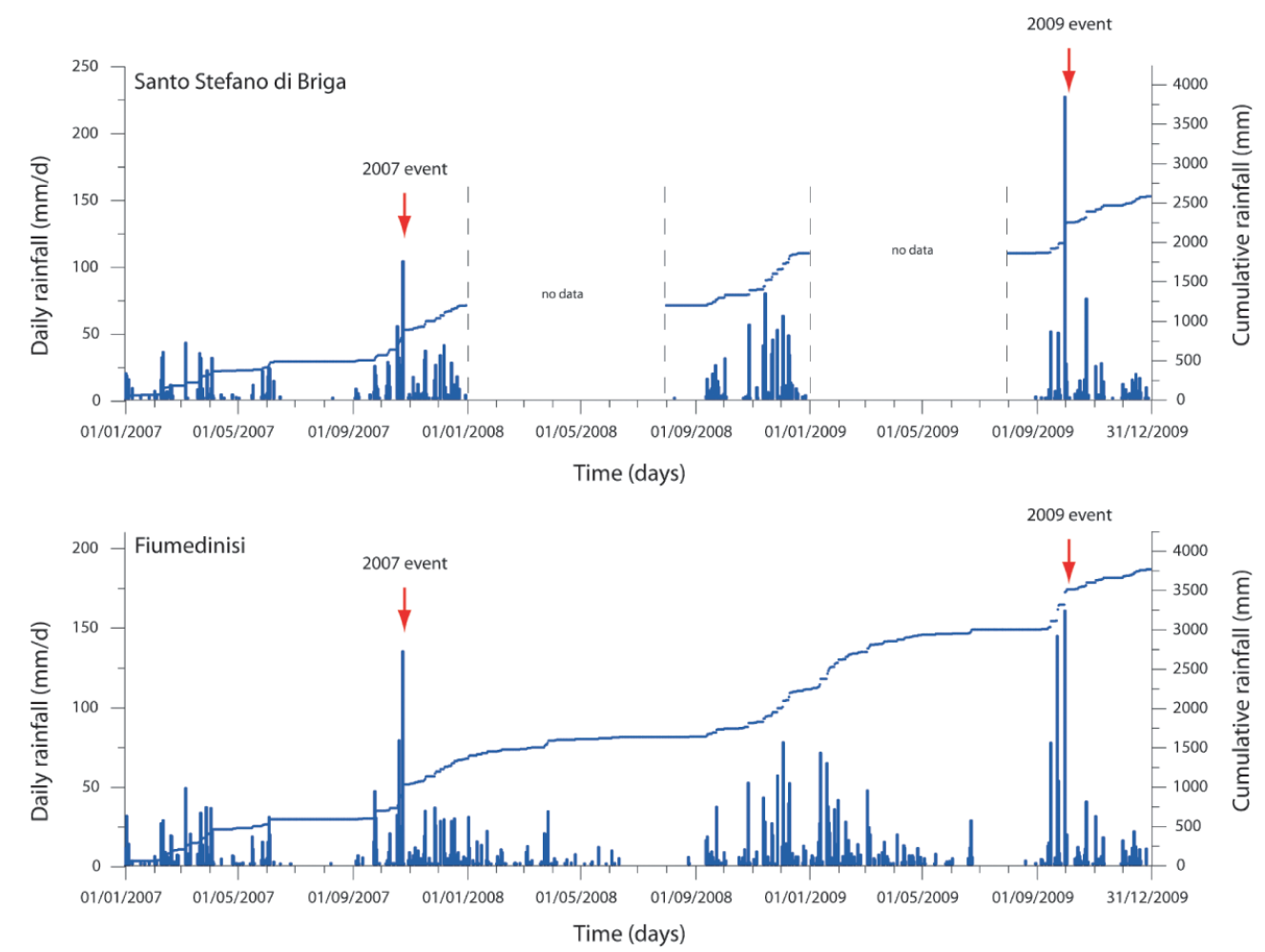

Fig. 2. Daily and cumulative precipitation data for the period January 2007 - December 2009.

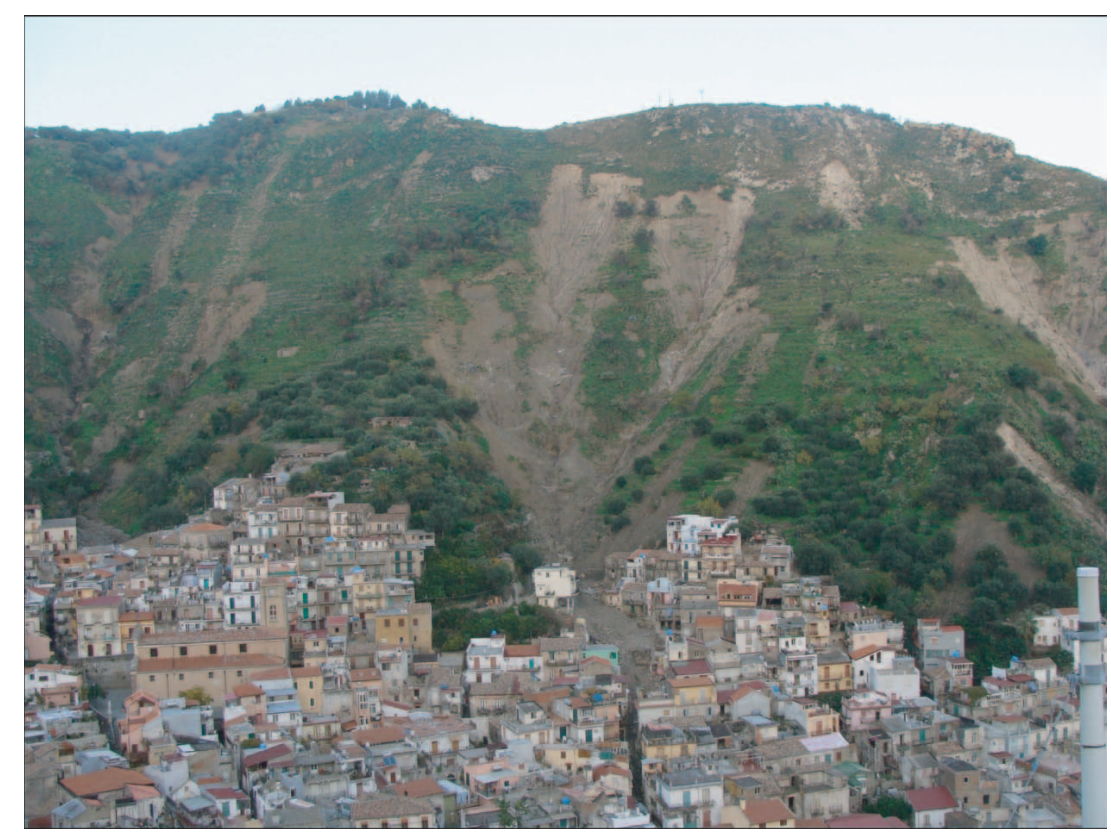

Fig. 3. Post-event panoramic view of Giampilieri.

The detachment sites are located at different heights, but usually in the upper sector of the slopes, near the crest (Fig. 3).

The 1 October 2009 landslides likely started as debris flow slide (Hungr et al., 2001), they may have undergone an evolu- tion by including soil, debris, vegetation and material resulting from the destruction of agricultural terraces (e.g., stone walls), during their moving downhill, thus, increasing density and consequent destructive power (see Bovis and Jakob, 1999). 


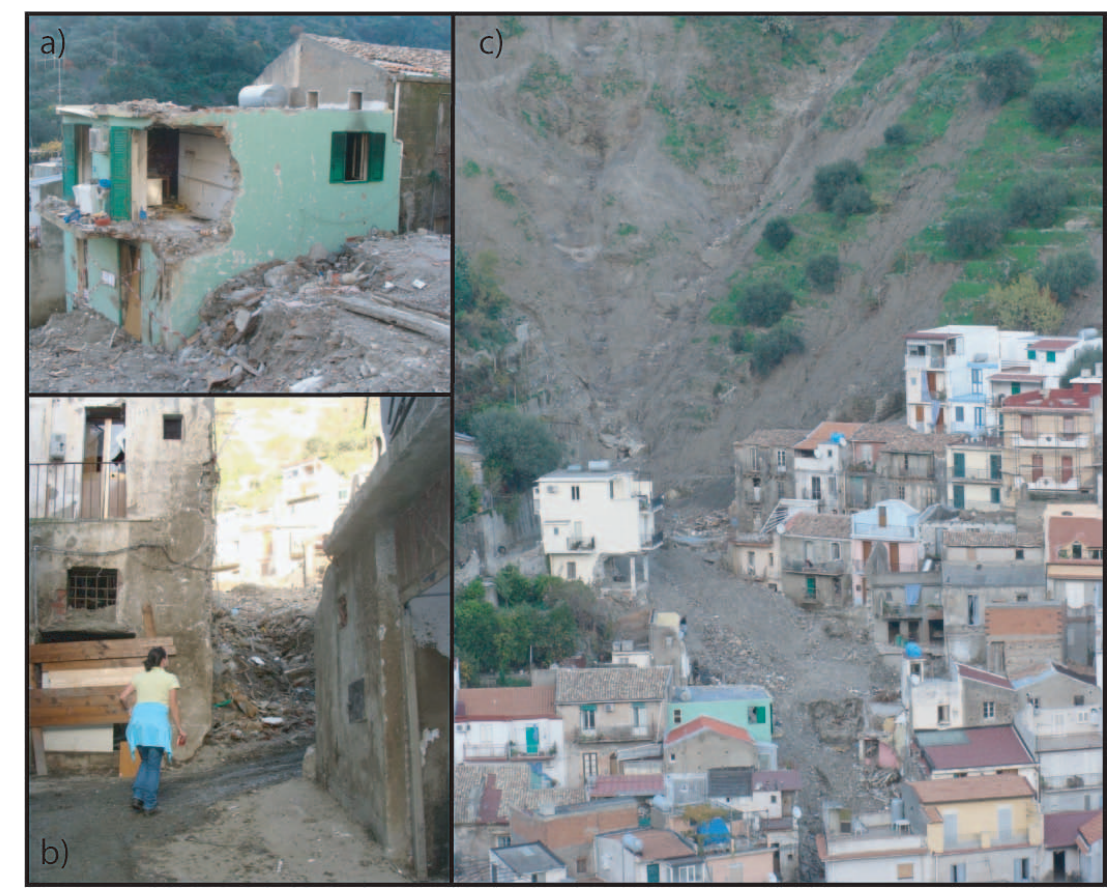

Fig. 4. Examples of the damages caused by one of the seven debris flows that occurred in Giampilieri. In (a) and (b) details of picture (c) are shown.

Most of the debris flows that occurred in the Messina area became diluted downstream assuming the character of a debris flood defined as a very rapid canalised surging flow of water, heavily charged with debris. With respect to a debris flow, a debris flood lacks longitudinal sorting and boulder fronts and the destructiveness is similar to that of a water flood (Hungr et al., 2001). Moreover, mud and debris flows were possibly characterised by an intermittent behaviour, due to the variable concentration of solid material and to possible local temporary weirs or bottlenecks formed in urban channels or village roads. Once they reached the village centre, these fast moving flows were channelled into the inhabited area, following the road network and then flooded into the Giampilieri torrent (Fig. 4).

While moving within the town the sliding mass increased in height (locally reaching the second floor of the houses), density and destructive power, as the result of both the reduction of cross-section and of inclusion of parts of destroyed buildings, cars and other objects (Fig. 4).

\section{Geological survey of the Giampilieri area}

The 1:2000 geological survey carried out immediately after the landslides resulted in the geological map (Fig. 5), which was integrated with a landslide map, derived from post-event stereo-photo interpretation. The study area is characterised by the occurrence of strongly weathered metamorphic rocks, topped by soil and alteration cover up to $1.5-$
$2 \mathrm{~m}$ thick. In the south-eastern sector of the village, the preCarboniferous medium-grade metabasites (amphibolites) of the Aspromonte Unit, representing the uppermost structural element of north-eastern Sicily, crop out. A high angle fault separates the amphibolites from the phyllites and metasandstones of the low-grade Mandanici Unit, belonging to the Variscan metamorphic complex, cropping out in the northwestern sector. Both the units generally appear highly fractured and characterised by closely-spaced cleavage systems.

The attitude of rock layers throughout the slope changes from SW-dipping in the phyllites to NNE-dipping in the metabasites (Fig. 5), possibly influencing the amount of debris accumulated along the slope. The Giampilieri village is built on detrital fan deposits, derived from ancient debrisflows.

\section{Giampilieri landslides description and triggering mechanisms}

The seven main landslides occurred on 1 October 2009 on the left bank of the Giampilieri stream (Fig. 6), which is more densely populated and was consequently more damaged, are described below. 


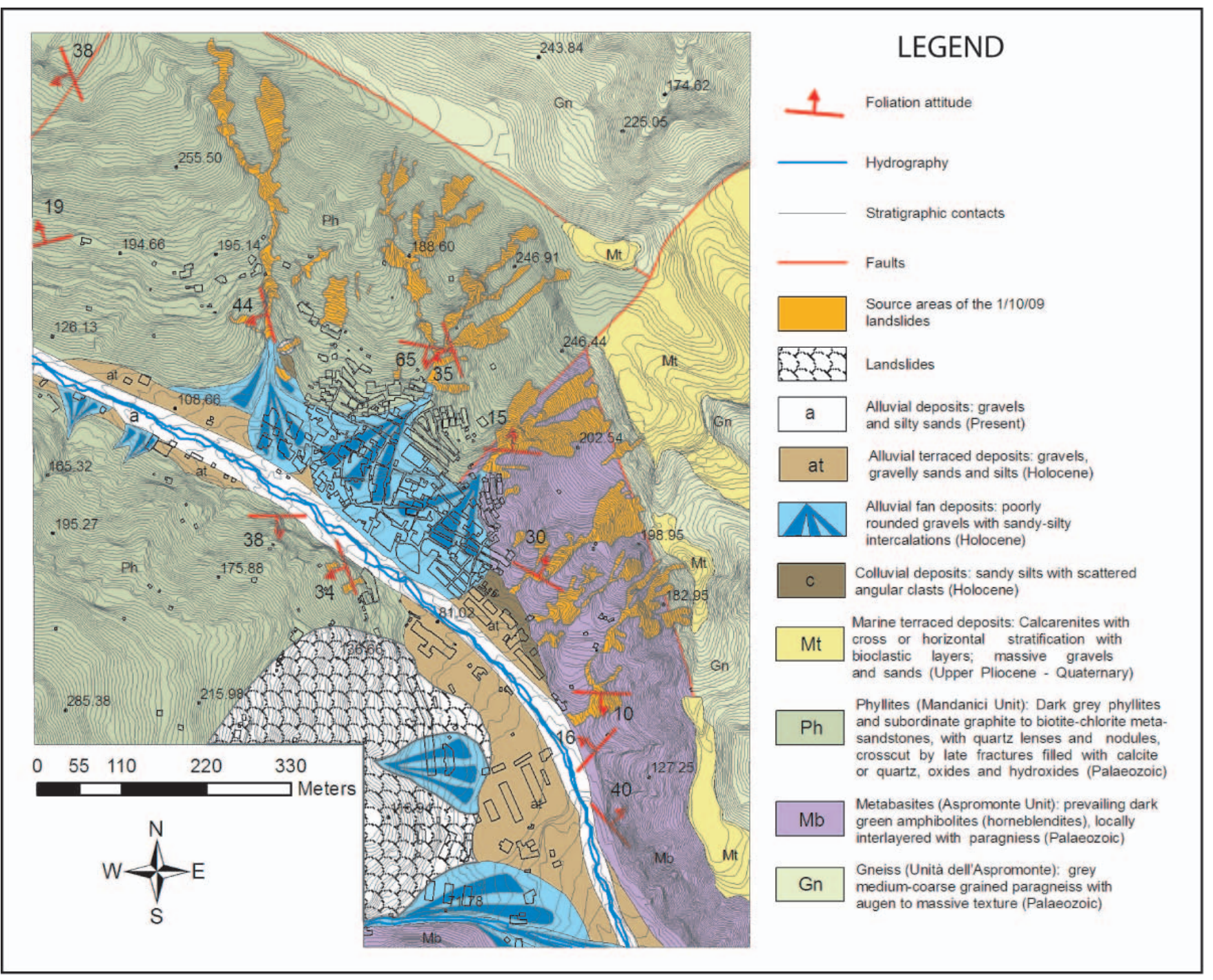

Fig. 5. Geologic map of Giampilieri, with location of 1 October 2009 landslides.

\subsection{Landslide on Loco Grande torrent (no. 1 in Fig. 6)}

The Loco Grande torrent originates at an elevation of about $300 \mathrm{~m}$ a.s.l. and flows into the Giampilieri torrent, at about $100 \mathrm{~m}$ a.s.l. after crossing the provincial road SP33, through a double cement pipe. Due to the increase of pore pressure as a consequence of the intense rainfalls, this landslide was triggered at an altitude of about $300 \mathrm{~m}$ a.s.l., probably due to the collapse of a dry stone wall, that caused the sliding material to invade the provincial road SP34 winding along the crest. Here, the material deposited caused undrained loading of the material located on the slope downstream, causing its fluidification. The movement initiated at the contact between the bedrock and the sediment cover, about $2 \mathrm{~m}$ thick. The slide started as a roto-translational movement and became translational downwards; then, it was likely the material entered the torrent channel, evolving into a flow, after the inclusion of water and travelled downstream with considerable kinetic energy (due to the naturally high slope inclination) corresponding to a velocity of about $1 \mathrm{~m} \mathrm{~s}^{-1}$. The maximum thickness of the material deposited in the run-out area is about $3 \mathrm{~m}$.

\subsection{Landslide along the Sopra Urno torrent (no. 2 in Fig. 6)}

This landslide started near the divide, where a number of detachment scarps can be identified corresponding to the fluvial incisions, and involved about a $2 \mathrm{~m}$-thick cover terrain. The loose terrain fell from the flanks of the secondary incisions into the torrent bed and reached the main stream. This landslide can be defined as a translational slide evolving into debris flow, caused by retrogressive undermining of the toe due to water erosion, which reduced the passive resistance at 


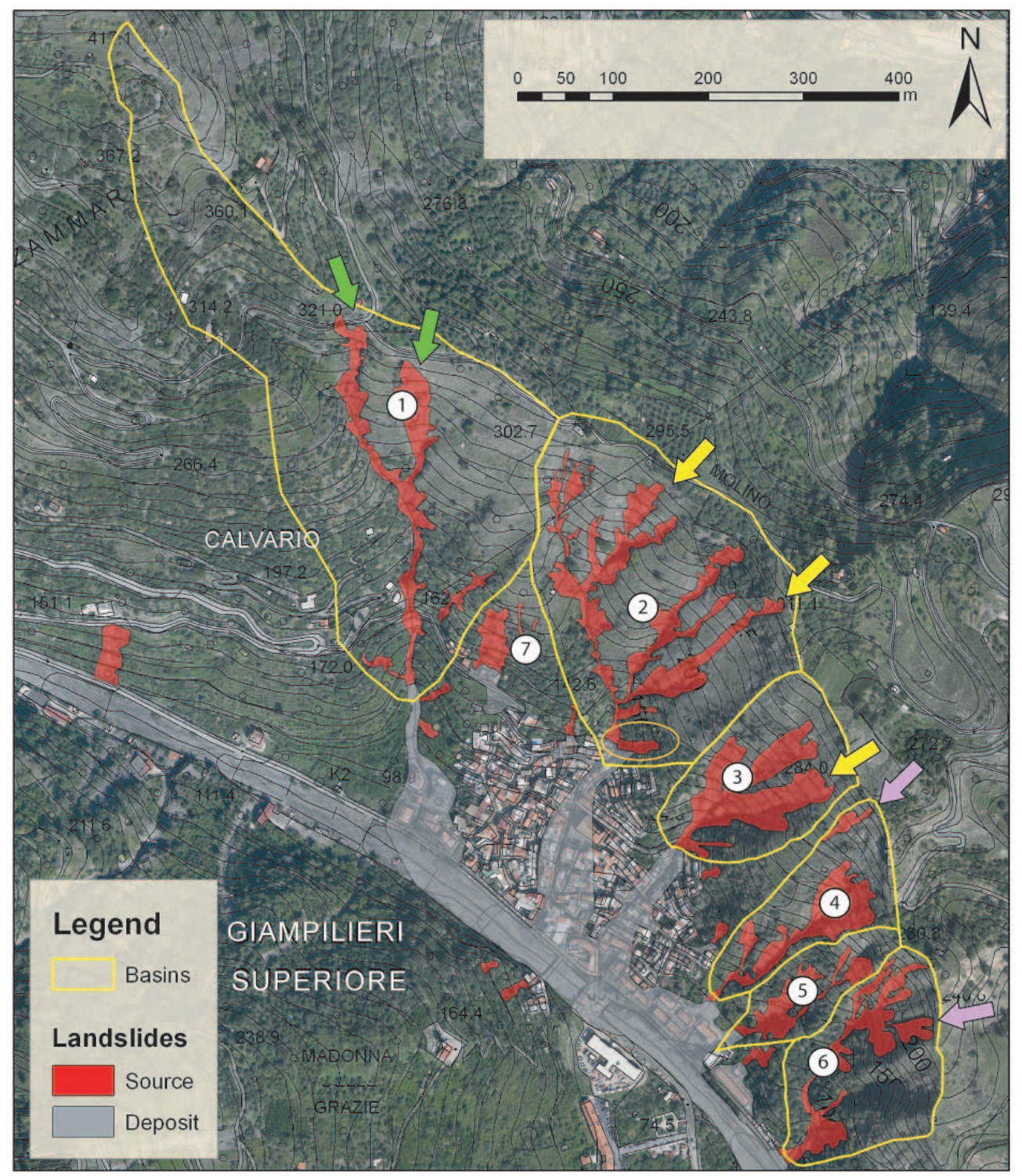

Fig. 6. Post event orthophoto of Giampilieri; the October 1st debris flows are shown in red. Definition of landslide boundaries were obtained from two days post-event orthorectified images. The yellow lines indicate catchment boundaries. Natural and human predisposing factors are also specified: yellow arrows for slope change, green ones for water accumulation related to anthropic activity (roads or agricultural terraces), purple arrows for retrogressive evolution reaching the divide. The light orange ellipse indicates a landslide probably triggered by toe undermining by the main stream.

the base of the mass. In fact, the Sopra Urno torrent, beginning at about $300 \mathrm{~m}$ a.s.l., flows into the Giampilieri torrent at $80 \mathrm{~m}$ a.s.l., after having passed through the central part of the village, along one of the main roads, through two small diameter pipes $(<1 \mathrm{~m})$. Close to the village, the mudflow swept away and destroyed the stabilisation structures built along the river bed after the 2007 event. The heterodimensional mass, characterised by a silty-clayey matrix, filled the main waterways, probably becoming a flow-type landslide because of the further input of water, thus, increasing its speed and its destructive power. It is worth noting that the left side of the stream, which was not terraced, failed, providing a considerable amount of material, unlike the terraced one, located on the right side. The deposited material, including very large boulders, reached a thickness of about $3 \mathrm{~m}$ and entered the lower floors of the houses and the adjacent streets.

\subsection{Landslide along Puntale torrent (no. 3 in Fig. 6)}

Like the Sopra Urno torrent, the Puntale torrent is also a left tributary of the Giampilieri creek. Starting at an altitude of about $280 \mathrm{~m}$ a.s.l., it flows into the main stream at $80 \mathrm{~m}$ a.s.l, after having passed through the urban area, along one of the 
Table 1. Volume and area (La/Ba) estimations for each landslide. Landslides volume was estimated using pre-event and post-event DEM.

\begin{tabular}{lllll}
\hline $\begin{array}{l}\text { Basin } \\
\text {-landslide } \\
\text { id }\end{array}$ & $\begin{array}{l}\text { Basin } \\
\text { area } \\
(\mathrm{Ba}) \\
\left(\mathrm{m}^{2}\right)\end{array}$ & $\begin{array}{l}\text { Landslide } \\
\text { area } \\
(\mathrm{La})\end{array}$ & $\begin{array}{l}\mathrm{La} / \mathrm{Ba} \\
(\%)\end{array}$ & $\begin{array}{l}\text { Landslide } \\
\text { volume } \\
\left(\mathrm{m}^{2}\right)\end{array}$ \\
\hline 1 & 116244 & 9749 & 8.38 & 13507 \\
2 & 73015 & 15479 & 21.19 & 13939 \\
3 & 25782 & 9879 & 38.32 & 8252 \\
4 & 18674 & 6546 & 35.05 & 6493 \\
5 & 11125 & 3262 & 29.32 & 2965 \\
6 & 27068 & 6725 & 24.84 & 4736 \\
7 & 12961 & 1876 & 14.47 & 817 \\
\hline
\end{tabular}

main roads which lacks any hydraulic work for transferring rain water. The landslide possibly started as a slide movement at a height of about $270 \mathrm{~m}$ a.s.l., just below the watershed, removing the thin superficial debris layer and moving along a narrow incision; it potentially turned into a flow of fluid material, after including large quantities of water. The landslide developed on a steeply inclined slope $\left(30^{\circ}-45^{\circ}\right)$ and transported along its path the material coming from the terraces located along slide. While entering the village, the mass swept away and destroyed or completely buried, up to a thickness of $3 \mathrm{~m}$, some of the houses before continuing its flow into the adjacent roads, reaching the Giampilieri torrent.

\subsection{Landslides on the southern sector of Giampilieri (no. 4, 5 and 6 in Fig. 6)}

These landslides started in the upper part of the slope, close to the primary school of Giampilieri, with a flow mechanism and then entered into the main incisions, located laterally with respect to the school building. The waters conveyed from these channels usually cross the street and flow into the Giampilieri torrent through a modest drainage structure. The material was mainly deposited against the school wall, entering the internal rooms and, in part, moving laterally into the adjacent houses, filling their lower floors. The landslide no. 6 blocked the main access road to Giampilieri.

\subsection{Landslide between Loco and Sopra Urno torrents (no. 7 in Fig. 6)}

This small landslide is characterised by a well-defined main crown; it started from an altitude of about $200 \mathrm{~m}$ a.s.l., probably because of the high pore pressure of the terrain, characterised by a mainly shaly-silty-sandy matrix. Despite of its reduced dimensions (the height difference between the main escarpment and the toe is about $50 \mathrm{~m}$ ), this flow swept away many buildings along its way down.

\section{DEM analysis}

A high resolution DEM analysis was used to carry out topographic, morphometric and hydrological quantitative analyses, based on the comparison between corrected pre- and post-event digital elevation models. In detail, the pre-event DEM, obtained from an interpolation of the contour lines resulting from a 1:1000 scale topographic map (geodetic heights) and the post-event DEM, elaborated from LIDAR data (ellipsoidic heights), were used to estimate the volume of material displaced during the investigated event.

Digital elevation models (DEMs) were primarily used to carry out an analysis of slope and aspect terrain factors, by using a $1 \mathrm{~m}$-resolution LIDAR-based DEM, integrated in ESRI ArcGIS environment. Slope has a strong influence on the production of debris material (Tunusluoglu et al., 2008). The village of Giampilieri is surrounded by very steep slopes, with an average gradient of about $25^{\circ}-35^{\circ}$, locally reaching $60^{\circ}$. Another crucial topographic attribute for the generation of debris material is aspect. The slopes involved in the October 2009 landslide phenomena are generally oriented towards south/south-west and the average slope is about 30$35^{\circ}$ (Figs. 7 and 8 ).

The area of each basin was determined and used as an estimate of the amount of water caught by each hydrographic basin, in order to discover the possible relation with the respective extension of the sliding area (Table 1).

The hydrographic network was also automatically extracted, using the ArcGIS algorithm for flow accumulation, which reconstructs the area drained by each cell in a grid (Fig. 9). The direct relation linking the area of maximum concentration of flow to the highest probability of landslide initiation is not always verified, pointing to other influencing factors being responsible for landslides initiation.

To take into account the differences in altimetric values, due to the different reference systems, a conversion to geodetic heights was made on the post event DEM using the ItalGEO model (Barzaghi et al., 2007). A height increase of $41.29 \mathrm{~m}$, found as the average difference between the ellipsoid and the geoid in the Giampilieri area, was applied. 


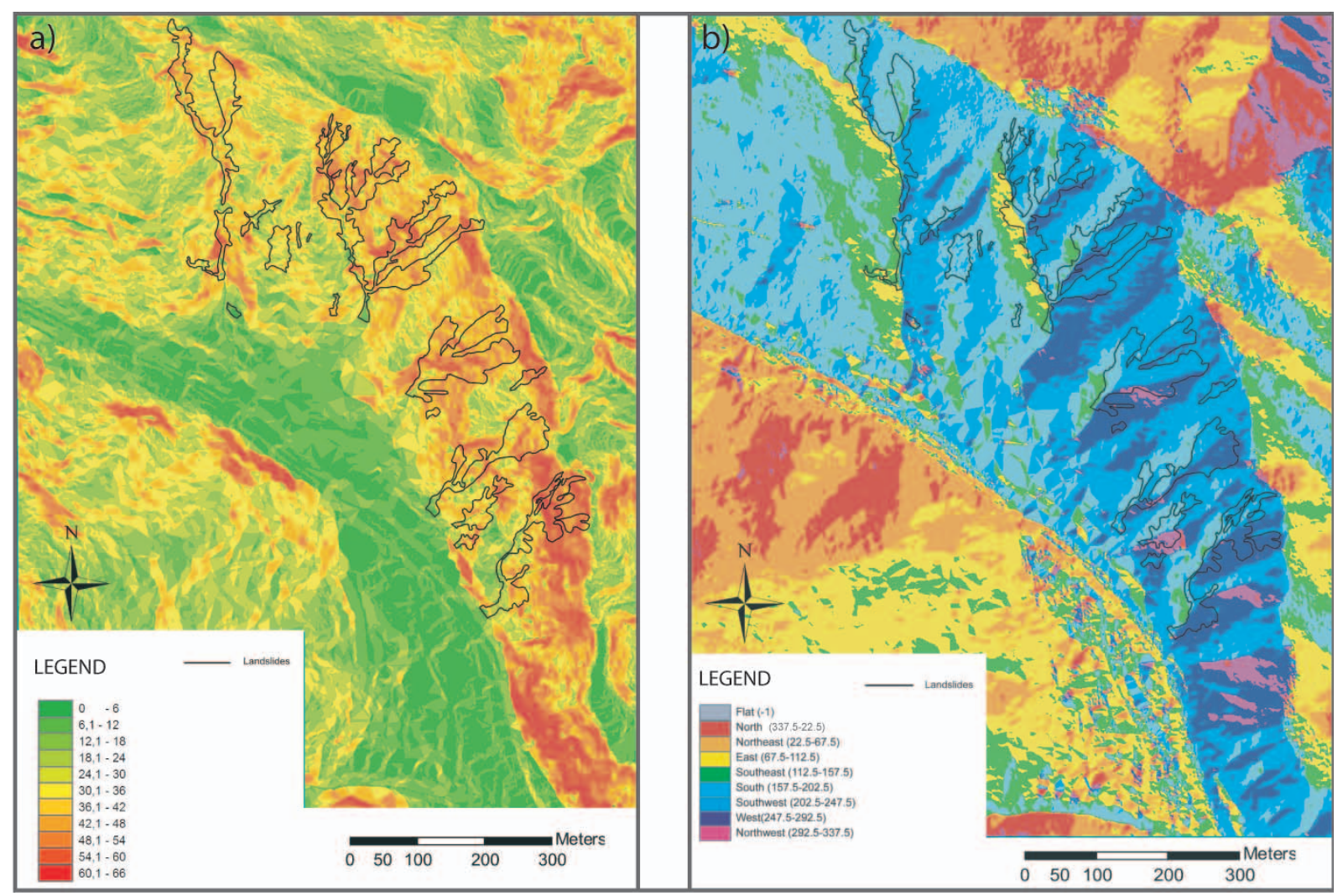

Fig. 7. (a) Localisation of detachment zones on the slope map, calculated from the pre-event DEM. Landslides affecting the area were identified through post-event orthorectified aerial images. (b) Map of October 2009 disruptions displayed onto the aspect map, with resolution of $1 \mathrm{~m}$, elaborated from LIDAR data.
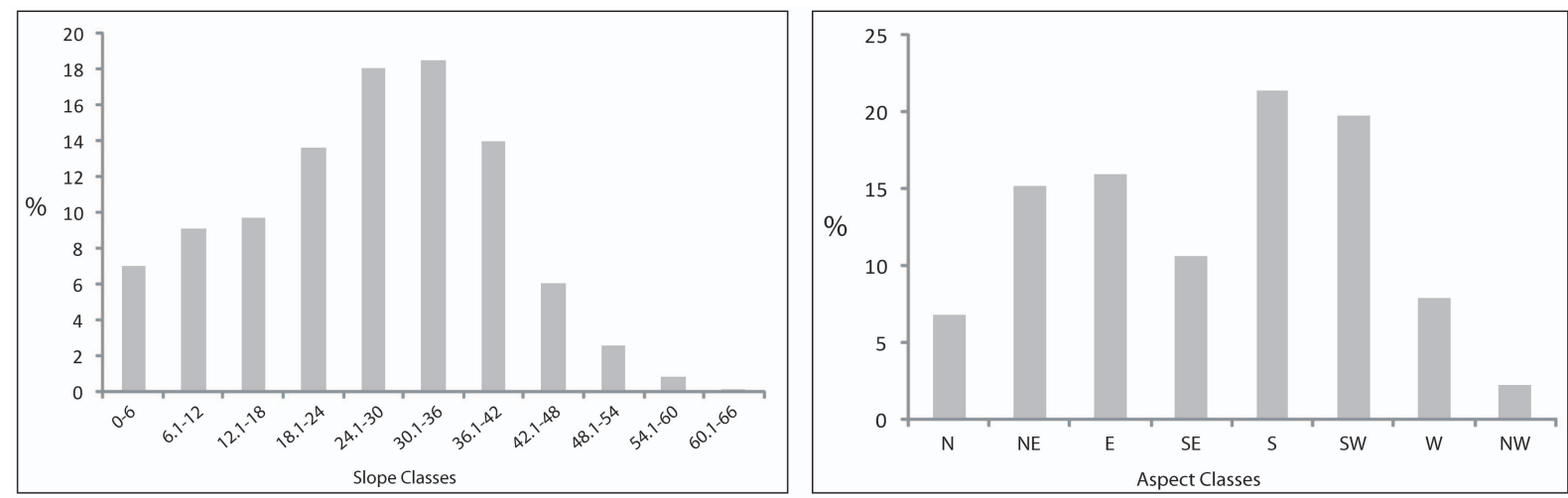

Fig. 8. (a) Histogram of slope classes (intervals of $6^{\circ}$ ) for the slopes affected by the landslides of the 1 October 2009. (b) Histogram of aspect classes.

Any possible error in the calculations, due to the shift between the two models, was reduced by applying progressive northwards and eastwards corrective shifts of the pre-event DEM ( $1 \mathrm{~m}$ in both directions at each iteration) and considering the post-event DEM as correctly positioned. In order to reduce errors and processing times, the analysis was carried out only on an area of about $2 \mathrm{~km}^{2}$, centred on the village of Giampilieri. Then, from the two overlapping models, an elevation difference raster file was obtained, formed by $1 \mathrm{~m}^{2}$ pixels associated to the average altitude difference: the volume difference (Table 1) with respect to a hypothetic zeroheight plane (corresponding to no height change) was obtained by using the Area and Volume tools in ESRI ArcGIS 3-D Analyst/Surface Analyst. The present attempt to estimate the landslide volumes allows the corresponding landslide magnitude to be obtained, which can be defined as the 


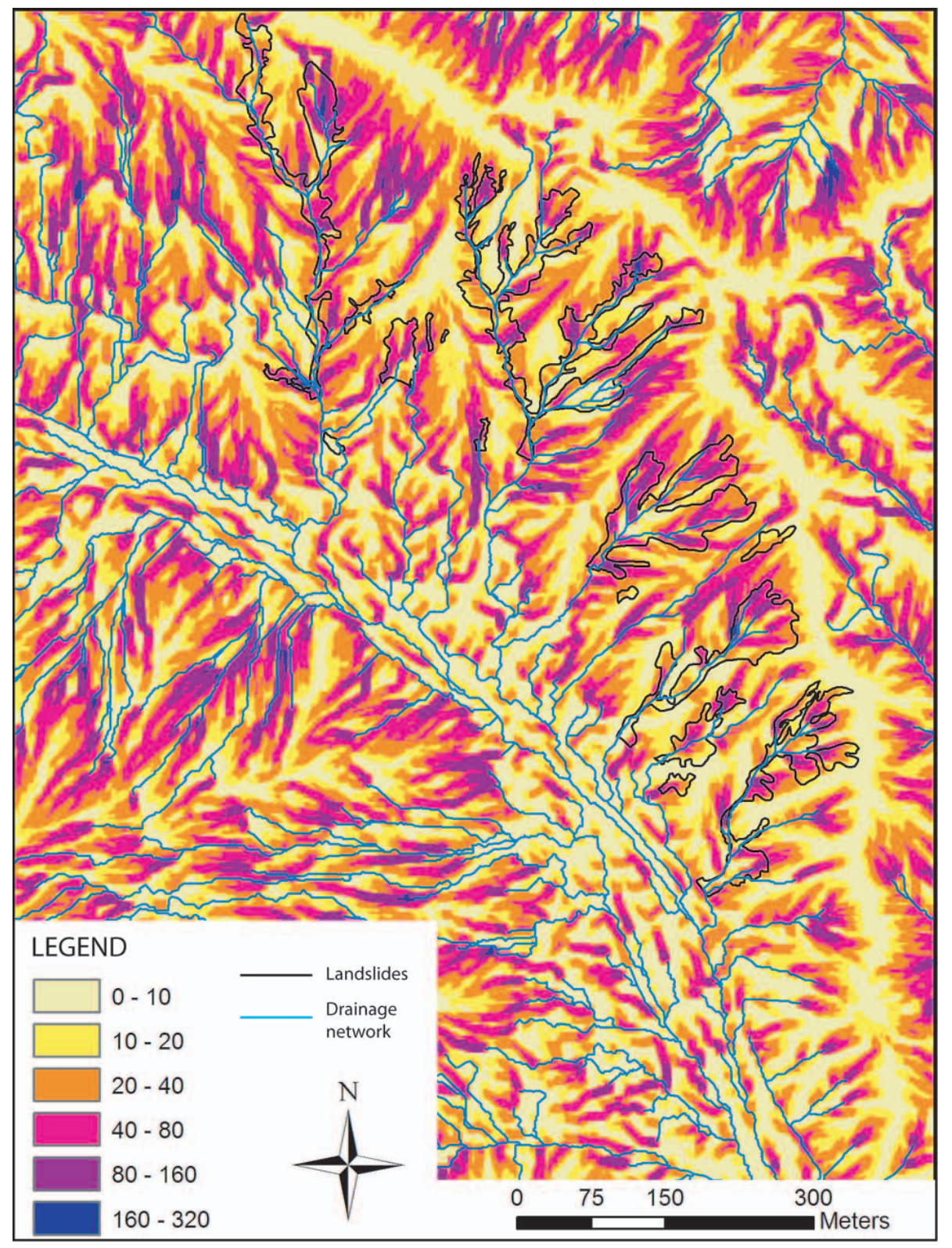

Fig. 9. Landslides drawn on the drained areas map of Giampilieri.

total volume of material moved to the deposition area during an event (Hungr et al., 2005).

The DEMs, after the removal of possible anomalous peak and sink cells (using the procedure described by Tarboton et al., 1991), are used for the elaboration of the flow direction models (Fig. 10). In a flow direction model (Tarboton et al., 1991), the direction of a drop in a cell is reported for every cell (i.e., towards which cell it would move amongst the adjacent cells). Based on this information, the flow accumulation models are elaborated following Jenson and Domingue (1988). In such models, every cell corresponds to the number of the upstream cells from which, according to the direction model, the water would flow towards that cell. This means that cells with high values represent the valleys in the height model, since they catch more water than the upstream ones, while the zero value cells correspond to the crests. In our specific case, high values are related to the points where the greatest accumulation of material occurred.

The flow accumulation models are used to reconstruct the drainage network, simply by imposing a suitable threshold and obtaining Boolean maps displaying 1 or 0 , depending if the cell receives or not the water from at least the chosen number of cells. These maps usually form continuous lines because, if a certain cell reaches the threshold value, all those located downstream generally exceed it. After a few attempts the threshold value of 3000 cells was considered suitable for 


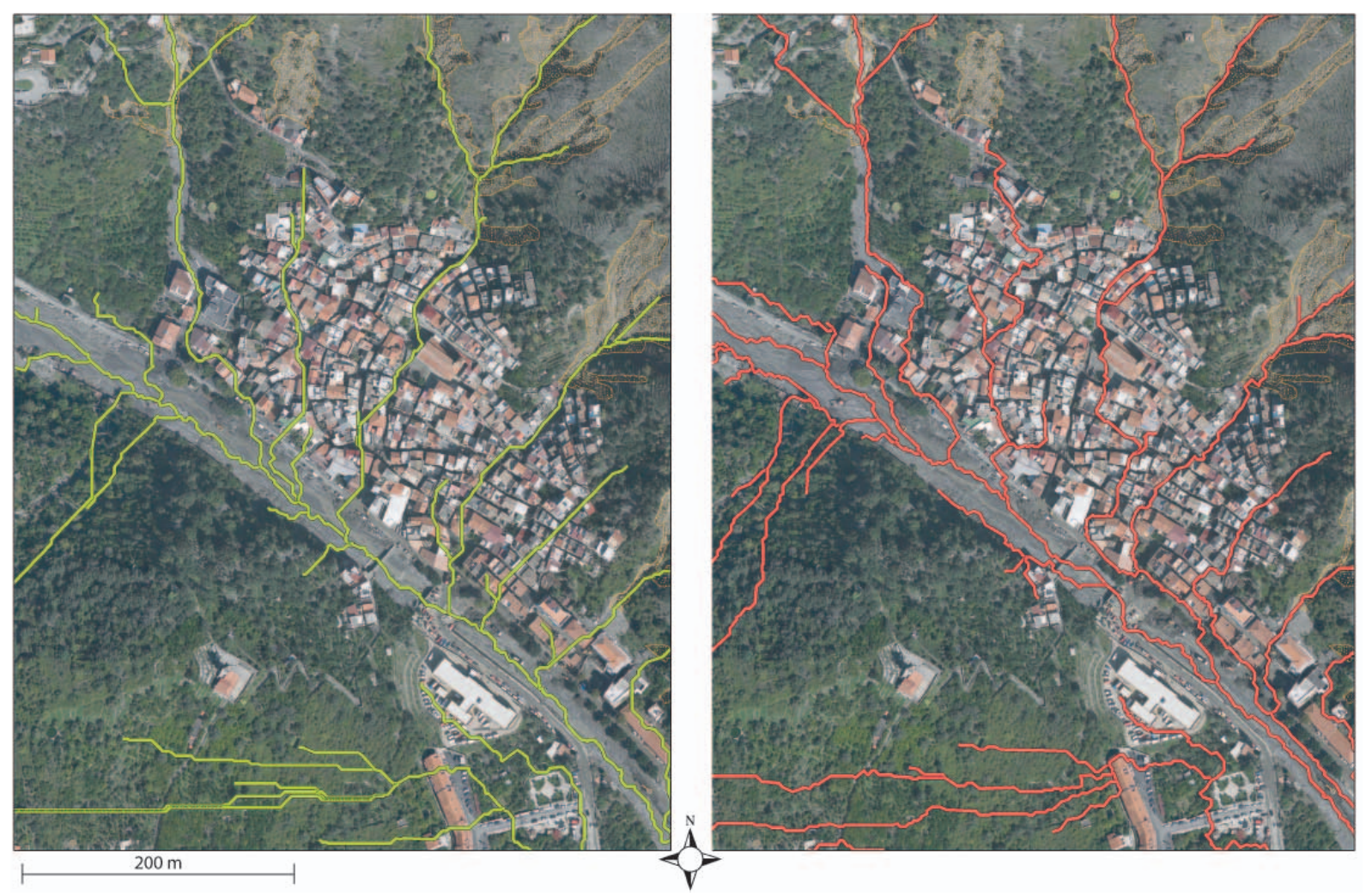

Fig. 10. Flow direction model. The natural flow (green lines) was determined from pre-event DEM. The urbanised flow (red lines) was derived from the pre-event DEM, by adding buildings obtained from a technical map, to show how the anthropic influence affected the flow direction.

the aims of our study, which studies the drainage pattern within inhabited areas. The obtained ideal paths of downstream material transportation were vectorised as polylines, to better visualise the flow direction. All the above described operations were carried out using the ESRI ARCINFO Spatial Analyst-Hydrologic Toolbox ${ }^{\mathrm{TM}}$.

\section{Landslide features related to geology}

Debris flow magnitude and frequency are functions of both rainfall intensity and terrain variables, such as slope relief and lithological characteristics, which have an influence on the availability of loose debris (Hungr et al., 1984; Cannon and Ellen, 1988; Fannin and Rollerson, 1993). Damage proportions, on their turn, depend on the amount and grain size of the available material, impact pressure and velocity (Fuchs et al., 2007; Quan Luna et al., 2011).

The surface extension and the landslide/catchment surface ratio obtained for each basin (Table 1 and Fig. 6) provide useful information on the general stability of each sector and on the amount of potentially unstable material on the slopes, by highlighting the percentage of the surface removed by the landslide.
The landslide volumes can be related to the different lithology of the bedrock, the widest phenomena occurring were the phyllites belonging to the Mandanici Unit crop out (Fig. 5). A quantitative assessment of the debris production potential of the mapped lithologic units can be undertaken following Tunusluoglu et al. (2008), who defined a debris source intensity index $\left(\mathrm{DSI}_{i}\right)$ for every lithology, as the ratio of the number of pixels including the debris source area of any lithology " $i$ " $\left(\mathrm{NPDS}_{i}\right)$ to the total number of pixels of the lithology " $i$ " in the whole study area $\left(\mathrm{AL}_{i}\right)$ :

$\operatorname{DSI}_{i}=\left(\mathrm{NPDS}_{i}\right) / \mathrm{AL}_{i}$.

where $\mathrm{AL}_{i}$ corresponds to the extension of each drainage area (i.e., the basins of Fig. 6). The extension of the landslides occurring for each lithology and the debris source intensity index are reported in Table 2.

\section{Data integration}

The results obtained from the different methodologies described above were integrated in a GIS environment to evaluate the tendency of landslides occurrence in the Giampilieri area. Four different parameters were considered in this study (slope, aspect, drained areas and lithology - following the 
Table 2. Parameters involved in the calculation of the DSI index. $\mathrm{Ph}=$ Phillites and metasandstones of Mandanici Unit; Amp = Amphibolites of the Aspromonte Unit and $\mathrm{Gn}=$ Gneiss of Aspromonte Unit.

\begin{tabular}{|c|c|c|c|c|c|}
\hline Basin- landslides id & Basin area & Litology & $\operatorname{Basin}\left(\mathrm{m}^{2}\right)$ & Landslides $\left(\mathrm{m}^{2}\right)$ & DSI \\
\hline \multirow{3}{*}{1} & \multirow{3}{*}{116244} & $\mathrm{Ph}$ & 116244 & 9749 & 0.0839 \\
\hline & & Amp & - & - & - \\
\hline & & $\mathrm{Gn}$ & - & - & - \\
\hline \multirow{3}{*}{2} & \multirow{3}{*}{73015} & $\mathrm{Ph}$ & 73015 & 15479 & 0.2120 \\
\hline & & Amp & - & - & - \\
\hline & & $\mathrm{Gn}$ & - & - & - \\
\hline \multirow[b]{2}{*}{3} & \multirow[b]{2}{*}{25782} & $\mathrm{Ph}$ & 6871 & 1250 & 0.1843 \\
\hline & & Amp & 15449 & 8477 & 0.5487 \\
\hline \multirow{4}{*}{4} & \multirow{4}{*}{18674} & $\mathrm{Gn}$ & 2889 & 152 & 0.0526 \\
\hline & & $\mathrm{Ph}$ & - & - & - \\
\hline & & Amp & 13822 & 5917 & 0.4281 \\
\hline & & $\mathrm{Gn}$ & 4556 & 629 & 0.1381 \\
\hline \multirow{3}{*}{5} & \multirow{3}{*}{11125} & $\mathrm{Ph}$ & - & - & - \\
\hline & & Amp & 10189 & 3262 & 0.3201 \\
\hline & & Gn & - & - & - \\
\hline \multirow[b]{2}{*}{6} & \multirow[b]{2}{*}{27068} & $\mathrm{Ph}$ & - & - & - \\
\hline & & Amp & 21666 & 5642 & 0.2604 \\
\hline \multirow{4}{*}{7} & \multirow{4}{*}{12961} & Gn & 4615 & 1083 & 0.2347 \\
\hline & & $\mathrm{Ph}$ & 12960 & 1876 & 0.1448 \\
\hline & & Amp & - & - & - \\
\hline & & $\mathrm{Gn}$ & - & - & - \\
\hline
\end{tabular}

DSI results) are reclassified using four different classes (Table 3). The integration of these parameters resulted in a map of the landslide prone areas (Fig. 11). These maps can be used as a starting point for a proper urban planning.

Particularly, two different kinds of map were produced. In the first one (Fig. 11a) all the elaborated parameters were considered, while in the second one (Fig. 11b), the aspect was omitted in order to obtain a method which could possibly be applied everywhere. Indeed this parameter (aspect) can be used only at local scale. The areas characterised by high and very high values correspond to the most sliding areas and are located on the south-eastern slopes.

\section{Discussion}

The data collected in this work confirm that the different characteristics of the landslides observed in the Giampilieri area are due to a complex interplay among the analyzed parameters.

Partly because of the intense fracturing and widespread and persistent foliation of the bedrock in the study area, it is strongly weathered and covered by a layer up to $1.5-2 \mathrm{~m}$ thick of loose material, which is unstable on the steep slopes and completely water-soaked. Thus, this matrix-supported chaotic mixture of fine and coarse material moved towards the valley, generally following the pre-existing flow lines. In detail, the movements initiated locally because of several predisposing factors: slope change, interaction with manmade structures (roads or agricultural terraces), toe undermining. In some cases the landslides extended retrogressively uphill to the main watershed.

Flows were fed by the erosion of debris deposits, soil and vegetation, by the detachment of large boulders of rock and 
Table 3. Reclassified values used for the data integration resulting in the map of the landslide prone areas.

\begin{tabular}{llllll}
\hline & & Slope $\left({ }^{\circ}\right)$ & Aspect $\left({ }^{\circ} \mathrm{N}\right)$ & Drained area $\left(\mathrm{m}^{2}\right)$ & Lithology \\
\hline \multirow{4}{*}{ Tendency } & Low & $<30$ & $0-90$ & $<40$ & Covers \\
& Medium & $30-40$ & $90-180$ & $40-80$ & Gneiss \\
& High & $40-50$ & $270-360$ & $80-120$ & Phyllites \\
& Very high & $>50$ & $180-270$ & $>120$ & Amphibolites \\
\hline
\end{tabular}

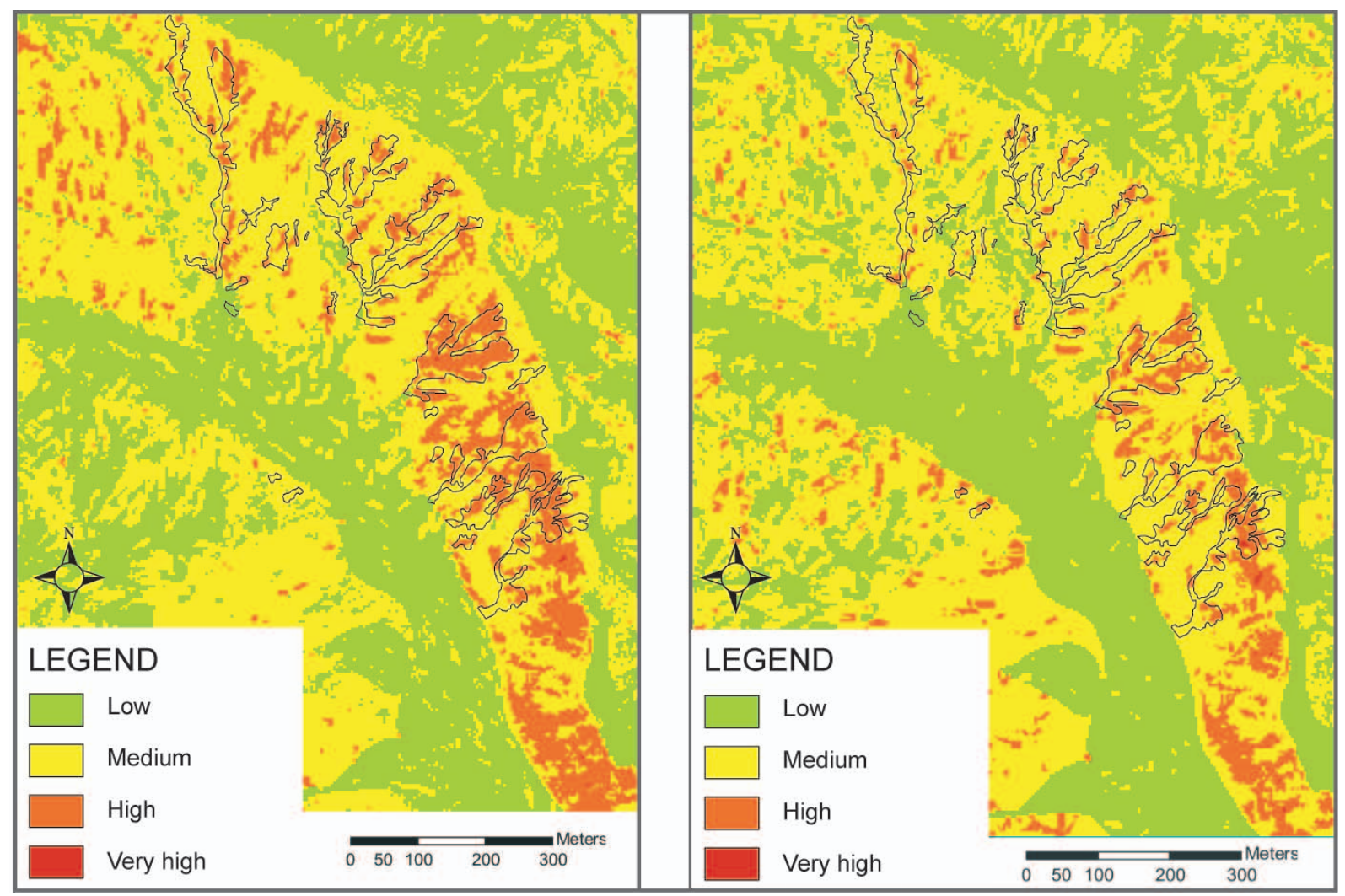

Fig. 11. Maps of landslide prone areas obtained using all the parameters (a) and omitting the aspect (b).

by the local destruction of terraces contained by stone walls, becoming exceptionally dense and characterised by a very high destructive power.

Regarding the slope features, the landslides prevalently occurred on SW oriented slopes (Fig. 7). Moreover, a clear correspondence between debris flows locations and areas characterised by steep slopes morphology $\left(35^{\circ}-45^{\circ}\right)$ also can be identified (Fig. 7).

As highlighted from the landslide to basin area ratio, most of the debris flows affected a large portion of the slope (up to $38 \%$ ), acting through a net of secondary channels (Table 1). The ratio between landslide volume and landslide area points to a shallow sliding surface, generally between 0.5 and $1.2 \mathrm{~m}$.

The estimated volumes obtained from DEM analysis could be affected by a general inaccuracy due to the simplification made to compare the pre-event and the post-event DEM. Indeed, the morphology of the landslide developed along the stream channel of the Loco Grande (basin 1 in Fig. 6) suggests a more superficial slip surface with respect to other basins (e.g., basin 3; Fig. 6), where the area affected by slope movements is wider.

The differences in landslide morphology could also be due to the different lithology on which the two landslides developed.

The analysis of the DSI index to evaluate the potential of each lithology to produce landslides suggests that the amphibolites are more prone to the development of debris flows than the phyllites; this point is in apparent contradiction with their expected geotechnical properties. In the amphibolites, the slip plane is likely located at a deeper level than in the phyllites, thus, creating a greater landslide volume. In general, data indicate that lithology indeed affects the volume of the landslide, but not its areal size. Then, the use of the DSI 
parameter to estimate the capacity of a certain lithology to produce debris can sometimes be misleading.

The landslides developed in the Giampilieri area caused differing amounts of damage. For example, landslides developed in basin 2 (Fig. 6; Table 1 and 2) caused fewer injuries than those in basin 3, even though the estimated volume is higher in the first case $\left(13939 \mathrm{~m}^{3}\right.$ vs. $8252 \mathrm{~m}^{3}$; see Table 1$)$. This discrepancy might be related to the different rheology of the mass, which is more fluid in basin 2 because of a major amount of drained water (i.e., higher basin extension) and/or to the different lithology of the material involved in the slide. In fact, in basin 2 the phyllites of the Mandanici Unit crop out, while basin 3 is developed on the metabasites of the Aspromonte Unit. While weathered phyllites produce fine grained debris, which easily turns into mud when wet, the metabasites can be altered into large blocks, which contribute to the increase of the destructive power of the sliding mass.

The maps of the landslide prone areas (Fig. 11), obtained by integrating four different parameters (slope, aspect, drained areas and lithology), identify the areas characterised by a high probability of sliding.

In Fig. 10 the comparison between natural and urbanised flow directions is shown. The analysis of flow accumulation models clearly suggests a moderate alteration of drainage paths, produced by urbanisation. Along most of the streams, the natural and urbanised flow directions are almost the same and coincide with the main roads of the village. Outside the urban area the difference in flow direction can be due to using different DEM. Post-event DEM derives from LIDAR acquisition (so that each $1 \mathrm{~m} \times 1 \mathrm{~m}$ cell has a point), while the pre-event DEM was obtained from an interpolation of isohypses derived from a 1:1000 topographic map). This difference may lead to inaccuracies in the reconstruction of the ridges and watersheds unless specific algorithms are used (Agricola et al., 2002). As a matter of fact, urbanisation did not modify the natural drainage network inside the old town, nor did it cause evident obstructions or deviations, since the water flow was channelled along the roads, built along the course of the rivers, or piped in manholes below them. Nevertheless, water bed sections were generally restricted; this situation had serious consequences on the extent of damage, since the buildings along and so close to such "street-rivers", besides reducing the hydraulic section, were also dangerously exposed to the devastating power of landslides. Only in the south-eastern sector of Giampilieri, the hydrographic net changes from natural to urbanised in relation to new buildings realised crossways with respect to the flow lines.

The map of the landslide prone areas and the flow models can be used jointly as a powerful tool to obtain a preliminary indication, useful for the future urban planning.

\section{Conclusions}

Rainfall-induced landslides are widespread phenomena worldwide which, often affect urbanised areas, causing intense damages and casualties (Saito et al., 2010; Montrasio et al., 2011; Chen et al., 2012; Huat et al., 2012). The management of the post-event phase needs for a fast evaluation of the involved areas and of the triggering factors that caused landslides. The latter are fundamental to evaluate the stability of the area affected by landslides in order to facilitate a quick and safe activities of the Civil Protection Authorities during the emergency.

Geologic and morpho-hydrologic features can represent predisposing factors to rainfall triggered landslides, usually recognisable as debris flows. Moreover, the severity of damage is also related to aspects of territorial management, including anthropisation, modifications to river courses and the reduction of hydraulic sections, variations of land use, etc.

Field surveys and stereo-photo geomorphological analysis revealed a significant human influence on determining landslide triggering causes as well as the final amount of damage. In particular, destruction and injuries in the built-up area of Giampilieri were made even more severe by the main water flow lines, made narrower due to building activity and enlargement of the urban area.

The case study of Giampilieri focuses the attention on the necessity of sustainable land use and reasonable urban management in areas characterised by a high hydrogeological hazard and on the tremendous destructive power of these phenomena, which are capable of causing destruction to such small villages.

The area maintains a high degree of hazard: deposits of poorly consolidated debris on steep slopes are potentially subject to remobilisation during rainy periods. Therefore, future management and localisation of urban expansion areas should hopefully be based on a detailed geological and geomorphological characterisation, pointing to establishing the position of potential source areas and the possible evolution of the landslides. A runout analysis (prediction of landslide motion and its effects) could provide valuable guidance for town management planning decisions and for the development of mitigation strategies.

Several integrated methodologies to study rainfall-induced debris flows were developed. For example Pasuto and Soldati (2004) integrated the historical analysis, aerial photo interpretation, field survey, morphometric and grain size analysis and structural analysis to study the evolution of debris flows in the Italian Dolomites; Tunusloglu et al. (2007) combined the stream power index (SPI), aspect, elevation, sediment transport capacity index (LS), plan curvature, profile curvature and slope to produce a debris source areas susceptibility map in south-western Turkey; Chen and Yu (2011) used the aerial photo interpretation, the flow direction and accumulation, the slope angles, the stream power index (SPI) and the topographic wetness index (TWI) to study debris 
flow and their source areas in Taiwan. The usefulness of each methodology is strongly dependent from the geological and geomorphological settings of the investigated area. Thus, the proposed operative procedure is not universally applicable because of the several different predisposing factors that can be related to the study area, nevertheless it can be useful in areas characterised by steep slopes formed by strongly fractured rocks.

Acknowledgements. This research was supported by the SAR.net2 Project founded by National Department of Civil Protection and by the EU FP7 DORIS Project.

The authors gratefully thank the colleagues from the Centres of Competence for Hydrogeological Risk of the National Department of Civil Protection (CNR-IRPI and Department of Earth Sciences University of Florence) and from the University of Catania: E. Foti and M. Maugeri and their teams for stimulating debate and logistic support and L. Tortorici and G. De Guidi, for providing geological background, as well as for discussion and help in the field. The teams of the national and regional Civil Protection Authorities are acknowledged for sharing data, field work assistance and permission given to publication. We thank Thomas Glade, Jan Blahut and M. G. Winter for the constructive revisions which helped to improve the manuscript.

Edited by: T. Glade

Reviewed by: M. G. Winter and J. Blahut

\section{References}

Agricola, B., Pareschi, M., Venditti, A., Facciorusso, M., Favalli, M., and Battistini, A.: Progetto Digitalia - un modello del terreno a maglia triangolare per il territorio nazionale, 6a Conferenza Nazionale ASITA, 1,71-76, 5-8 Novembre 2002.

Antonioli, F., Kershaw, S., Rust, D., and Verrubbi, V.: Holocene sealevel change in Sicily and its implications for tectonic models: new data from the Taormina area, northeast Sicily, Mar. Geol., 3293, 1-19, 2003.

Ardizzone, F., Basile, G., Cardinali, M., Casagli, N., Del Conte, S., Del Ventisette, C., Fiorucci, F., Garfagnoli, F., Gigli, G., Guzzetti, F., Iovine, G., Mondini, A. C., Moretti, S., Panebianco, M., Raspini, F., Reichenbach, P., Rossi, M., Tanteri, L., and Terranova, O.: Landslide inventory map for the Briga and theGiampilieri catchments, NE Sicily, Italy, Journal of Map, 8, 176180, 2012.

Barzaghi, R., Borghi, A., Carrion, D., and Sona, G.: Refining the estimate of the Italian quasi-geoid, Bollettino di Geodesia e Scienze Affini, Firenze, Anno LXVI, 3, 145-160, 2007.

Ben Avraham, Z., Boccaletti, M., Cello, G., Grasso, M., Lentini, F., Torelli, L., and Tortorici, L.: Principali domini strutturali originatesi dalla collisione neogenico-quaternaria nel Mediterraneo centrale, Mem. Soc. Geol. It., 45, 453-462, 1990.

Bonardi, G., de Capoa, P., Di Staso, A., Estevez, A., Mart'ınMart' $\iota$ n, M., Mart' $\iota$ n-Rojas, I., Perrone, V., and Tent-Mancl'us, J. E.: Oligocene to Early Miocene depositional and structural evolution of the Calabria-Peloritani Arc southern subterrane
(Italy) and geodynamic correlations with the Spain Betics and Morocco Rif. Geodinamica Acta, 16, 149-169, 2003.

Bovis, M. J. and Jacob, M.: The role of debris supply conditions in predicting debris flow activity, Earth Surf. Process. Landf., 24, 1039-1054, 1999.

Brunetti, M. T., Peruccacci, S., Rossi, M., Luciani, S., Valigi, D., and Guzzetti, F.: Rainfall thresholds for the possible occurrence of landslides in Italy, Nat. Hazards Earth Syst. Sci., 10, 447-458, doi:10.5194/nhess-10-447-2010, 2010.

Cannon, S. H. and Ellen, S. D.: Rainfall that resulted in abundant debris flow activity during the storm, in: Landslides, Floods, and Marine Effects of the Storm of January 3-5, 1982, in the San Francisco Bay Region, California US Geological Survey, Professional Paper 1434, 27-34, 1988.

Carson, S. H.: Regional rainfall-threshold conditions fo abundant debris flow activity, in: Landslides, Floods and marine Effects of the Storm of 3-5 January 1982, edited by: Ellen S. D. and Wieczorek, G. F., in the San Francisco bay Region, California Prf. pap. US Geol. Surv., 1434, 35-42, 1988.

Chen, C. Y. and Yu, F. C.: Morphometric analysis of debris flows and their source areas using GIS, Geomorphology, 129, 387-397, 2011.

Chen, H. X., Zhang, L. M., Chang, D. S., and Zhang, S.: Mechanisms and runout characteristics of the rainfall-triggered debris flow in Xiaojiagou in Sichuan Province, China. Natural Hazards, 1-21, 62, 1037-1057, 2012.

Cruden, D. M. and Varnes, D. J.: Landslide types and processes, in: Landslides: Investigation and Mitigation, edited by: Turner A. K. and Shuster, R. L., Transp. Res. Board, Spec. Rep, 247, 36-75, 1996.

Fannin, R. J. and Rollerson, T. P.: Debris flows: some physical characteristics and behaviour, Canadian Geotechn. J., 30, 71-81, 1993.

Fuchs, S., Heiss, K., and Hübl, J.: Towards an empirical vulnerability function for use in debris flow risk assessment, Nat. Hazards Earth Syst. Sci., 7, 495-506, doi:10.5194/nhess-7-4952007, 2007.

Govi, M. and Sorzana, P. F.: Landslide susceptibility as a function of critical rainfall amount in Piedmont Basin (North-Western Italy), Studia Geomorphologica Carpatho-Balcanica, 14, 43-61, 1980.

Guzzetti, F., Peruccacci, S., Rossi, M., and Stark, C. P.: Rainfall thresholds for the initiation of landslides in central and southern Europe, Meteorol. Atmos. Phys., 98, 239-267, 2007.

Huat, L. T., Ali, F., and Ibrahim, A. S.: An investigation on one of the rainfall-induced landslides in Malaysia, Electronic J. Geotechn. Eng., 17, 435-449, 2012.

Hungr, O., Morgan, G. C., and Kellerhals, R.: Quantitative analysis of debris torrent hazards for design of remedial measures, Canadian Geotech. J., 21, 663-677, 1984.

Hungr, O., Evans, S. G., Bovis, M. J., and Hutchinson, J. N.: A review of the classification of landslides of the Flow Type, Environ. Eng. Geosci., VII(3), 221-238, 2001.

Hungr, O., McDougall, S., and Bovis, M.: Entrainment of material by debris flows, edited by: Jakob, M. and Hungr, O., Debris-flow Hazards and Related Phenomena, Springer, Berlin Heidelberg, 135-158, 2005.

Hungr, O., McDougall, S., Wise, M., and Cullen, M.: Magnitudefrequency relationships of debris flows and debris avalanches in relation to slope relief, Geomorphology, 96, 355-365, 2008. 
Iverson, R. M.: The physics of debris flows, Rev. Geophys., 35, 245-296, 1997.

Jenson, S. K. and Domingue, J. O.: Extracting Topographic Structure from Digital Elevation Data for Geographic Information System Analysis, Photogramm. Eng. Rem. Sens., 54, 11, November 1988, 1593-1600, 1988.

Johnson, A. M.: Debris flow, Slope Stability, in: Wiley-Interscience Publication, edited by: Brunsden, D. and Prior, D. B., Chirchester, 257-362, 1984.

Lentini, F., Grasso, M., and Carbone, S.: Introduzione alla geologia della Sicilia e guida all'escursione, Conv. Soc. Geol. Italiana Naxos/Pergusa, 20-25 April 1987.

Lentini, F., Carbone, S., and Catalano, S.: Main structural domains of the central mediterranean region and their tectonic evolution, Boll. Geof. Teor. e Appl., 36, 103-125, 1994.

Lentini, F., Carbone, S., Catalano, S., Di Stefano, A., Gargano, C., Romeo, M., Strazzulla, S., and Vinci, G.: Sedimentary evolution of basins in mobile belts: examples from tertiary terrigenous sequences of the Peloritani Mts (NE Sicily), Terra Nova, 7, 161$170,1995$.

Lentini, F., Catalano, S., and Carbone, S.: Carta Geologica della Provincia di Messina, Scala 1:50.000, Selca, Firenze, 2000.

Messina, A., Somma, R., Careri, G., Carbone, G., and Macaione, E.: Peloritani continental crust composition (southern Italy): geological and petrochemical evidences, Bollettino della Società Geologica Italiana, 123, 405-441, 2004.

Montrasio, L., Valentino, R., and Losi, G. L.: Towards a real-time susceptibility assessment of rainfall-induced shallow landslides on a regional scale, Nat. Hazards Earth Syst. Sci., 11, 1927-1947, doi:10.5194/nhess-11-1927-2011, 2011.

Moser, M. and Hohensinn, F.: Geotechnical aspects of soil slip in Alpine Regions, Eng. Geol., 19, 185-211, 1983.

Ogniben, L.: Nota illustrativa dello schema geologico della Sicilia nord-orientale, Riv. Miner. Siciliana, 11, 183-212, 1960.
Pasuto, A. and Soldati, M.: An integrated approach for hazard assessment and mitigation of debris flows in the Italian Dolomites, Geomorphology, 61, 59-70, 2004.

Pierson, T. C.: Flow behavior of channelized debris flows, Mount St. Helens, Washington, edited by: Abrahams, A. D., Hillslope Processes, Allen and Unwin, Boston, Mass., 269-296, 1986.

Pierson, T. C., Janda, R. J., Thouret, J. C., and Borerro, C. A.: Perturbation and melting of snow and ice by the 13 November 1985 eruption of Nevado del Ruiz, Colombia, and consequent mobilization, flow, and deposition of lahars, J. Volcanol. Geotherm. Res., 41, 17-66, 1990.

Quan Luna, B., Blahut, J., van Westen, C. J., Sterlacchini, S., van Asch, T. W. J., and Akbas, S. O.: The application of numerical debris flow modelling for the generation of physical vulnerability curves, Nat. Hazards Earth Syst. Sci., 11, 2047-2060, doi:10.5194/nhess-11-2047-2011, 2011.

Saito, H., Nakayama, D., and Matsuyama, H.: Relationship between the initiation of a shallow landslide and rainfall intensity-duration thresholds in Japan, Geomorphology, 118, 167-175, 2010.

Tarboton, D. G., Bras, R. L., and Rodriguez-Iturbe, I.: On the Extraction of Channel Networks from Digital Elevation Data, Hydrol. Process., 5, 81-100, 1991.

Tunusluoglu, M. C., Gokceoglu, C., Nefeslioglu, H. A., and Sonmez, H.: Extraction of potential debris source areas by logistic regression technique: a case study from Barla, Besparmak and Kapi mountains (NW Taurids, Turkey), Environ. Geol., 54, 922, doi:10.1007/s00254-007-0788-5, 2008.

Wieczorek, G. F.: The effect of rainfall intensity and duration on debris flows in Central santa Cruz Mountains, California, in: debris Flows/Avalances: process, recognition and mitigation, edited by: Costa, J. E. and Wieczoreck, G. F., Rev. Engng. Geol. (Geol. Soc. Am.), 7, 93-104, 1987.

Zimmermann, M. and Haeberli, W.: Climatic Change and Debris Flow Activity in High-Mountain Areas - A Case Study in the Swiss Alps, Greenhouse-Impact on Cold-ClimateEcosystems and Landscapes, Catena Suppl. 22, 59-72, 1992. 